\section{Bruno DALLAGO}

\section{SME POLICY AND \\ COMPETITIVENESS IN HUNGARY}

Small and medium-sized (SMEs) enterprises in Hungary account for $\mathbf{9 9 . 9 \%}$ of all enterprises and for more than two thirds of employment. Since transformation started in 1989 they have been the only net makers of In spite of such remarkable importance, results have been modest compared to the amount of Hungarian and foreign, mostly EU resources poured into the sector. Less than a sixth of SMEs are fast-growing and only a tiny minority of SMEs make use of bank credit. According to various indicators and in spite of bright spots, the SMEs context is problematic and SMEs features are often unfavourable and hardly competitive. In recent years the goal of upgrading SMEs and strengthening their contribution to the economy has acquired central position among policy goals and activity. Although progress has been made, the results are weak and in some cases drawbacks have happened. The paper starts from analysing the SMEs situation, reviews the main features of the recently implemented policy strategies, assesses whether these strategies are appropriate to address the situation, including the effects of the domestic and international crises, and considers whether the targets pursued are realistic and important, and the instruments considered in line with the targets

\section{Keywords: Hungary, SMEs, Transformation, Entrepreneurship, Competitiveness, Policies, Crisis, Strategy}

Transformation is about creative destruction: disman- damental component of the economies competitivetling the old economic, political and social system and ness both in general (Audretsch, 2006; Erixon, 2009a: fostering a new one. A similar observation holds for eco- Gries - Naudé, 2010; Schmitz, 2004) and in the case of nomic, political and social actors. The issue of creative transformation economies (MacIntyre - Dallago, 2003; destruction has been considered during transformation Aidis - Welter, 2008; Dallago - Guglielmetti, 2010). in Central and Eastern European Countries (CEECs) Along with the advantages of diffused entrepreneur(Murrell, 1992). Within it the importance of bottom-up ship and the favourable consequences for innovation, processes in general and that of the creation of small in transformation economies SMEs can embody market and medium-sized enterprises (SMEs) have been debat- institutions and support their evolution much faster and ed since the beginning (Kornai, 1990; Dallago, 1991). at lower cost than more bureaucratic and conservative However, policies have been dominated by the need to large companies. The latter have anyway to go through

stabilise, liberalise, and privatise quickly and on large costly and lengthy privatisation and restructuring be(Stabilise, liberilise, and privatise quickly and on large scale (Sachs, 1993, Fryd mach - Rapanski, 1994) ac(Wilis to the 1994; Rodrik, 2007). Willans, 1994 , Rodrik, 2007).

Large scale privatisation has led to remarkable formal success: by the end of the Nineties the economy was dominated by privately owned enterprises in nearly all former socialist countries. In spite of this forma success and improvement in restructuring (Fabrizio al., 2009), ${ }^{2}$ CEEC economies have remained vulnerable and their enterprises hardly competitive. There are important reasons to maintain that SMEs are a funre strengthening their competitiveness.

Enterprises competitiveness is of great importance for modern economies and their management. This importance has inced with teepering of the tranformation press amidt growing integrtion of worto

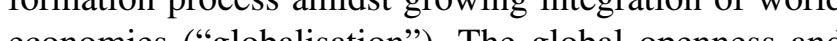
economies (globalisation"). The global openness and integration of economies have led in fact to deeper coordination of macro-policies, which can now be used by national governments only amidst many limits. Consequently, the differential push to competitiveness has been coming primarily from the institutional and micro- economic components of the economy. Entrepreneu ship and SMEs foundation and upgrading feature prom nently among the latter. In view of these developments, international and specialised organisations have tried to assess the factors supporting the innovative and competitive effect of entrepreneurship and SMEs (Doin Business, 2009a; Kauffman Foundation, 2007; OECD, 2008b). For countries in transformation, diffused entrepreneurship, enterprise foundation and upgrading have a particular importance for growth and competitiveness both for the requests of the transformation process and both for the rects of transformation process and policies have been dealing with SMEs as a size category more than for their critical role in the economy.

Among transformation countries Hungary presents
Amente perhaps the greatest puzzle. Thanks to the important attempts at reforming her economy since 1968 and again during the Eighties (Kornai, 1986), Hungary was consiered to be the frontrunner in transformation. However, since 1989 the country suffered various policy and transformation setbacks that increased the economic, socia and political vulnerability and led to spread dissatisfaction. ${ }^{3}$ Enterprises entered transformation with importan advantages: fundamental laws for large companies were approved in the second part of the Eighties and SMEs boomed since early Eighties (Dallago, 1989). During the Doned since enty the Nineties the capit and the nut sion. During this decade one Hungarian out of ten was registered as a businessman. In spite of this success, the Hungarian economy lacked momentum and large pat of the enterprises was not competitive and aimed at survival or only existed on statistical paper (Szirmai, 2003). Problems continued through the foll owing decade. Indeed, Hungary' performance is below average among CEECs according to various competitiveness rankin and SMEs are the least efficient by international standards (MNDE, 2009).

It is in this perspective that in recent years the Hungarian government has considered the disappointing situation with entrepreneurship and SMEs as one of the cicuses of the unstisfactory pefformace of the econcany. This convincenent has but accelered since the

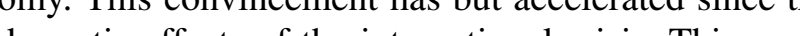
dramatic effects of the international crisis. This paper considers what went wrong with SMEs, which const al drawback. The next sections consider some data an information (Section 1) that depict the unsatisfactory situation of Hungarian SMEs, particularly concerning competitiveness (Section 2). Section 3 deals with the main individual factors that are behind the strategy to foster SMEs and Section 4 examines the effects of the international crisis and the new policy strategy. Section concludes.

\section{Overview of the SME sector}

Although large state owned firms dominated the economy during the socialist period, small and medium-sized enterprises (SMEs) were remarkably important particularly since the 1968 economic reform (Dallago, 1989). In the process of transformation many new SMEs were founded, through genuine greenfield investment, spinprive fits and "spontaneous" pher whelling are presently small and medium-sized and they provide more than two thirds of employment (table 1) and 80\% of GDP (Estrin et al., 2009). Consequently, their competitiveness fundamentally influences the performance of the whole economy. However, a clear dualism appeared between the modern foreign-owned sector and the less dynamic domestic sector. The latter includes most SMEs which do not perform substantial investments and make use of underground economic practices (such as tax evasion) (Szirmai, 2003).

SMEs have been defined in Act XXXIV of 2004 which has confirmed the Hungarian definition and practice to the Eur 6 Man Comission recomition 2003/361/EC of 6 May 2003. Stating from 1 Jation 2005, SMEs defin (cian, cial and ownership issues. These concerned particularly the use of consolidated buget and the exclusion from the SME category of those enterprises whose capital is owned for more than $25 \%$ by the state, municipalities or large companies, separately or jointly. This criterion does not apply to institutional investors.

Size distribution of Hungarian registered SME

(2005, in percent of all enterprises according to workforce size categories)

\begin{tabular}{|l|c|c|c|c|c|}
\hline & $\mathbf{0 - 1}$ & $\mathbf{2 - 9}$ & $\mathbf{1 0 - 4 9}$ & $\mathbf{5 0 - 2 4 9}$ & SME total \\
\hline $\begin{array}{l}\text { Number of } \\
\text { enterprises* }\end{array}$ & 75.6 & 20.2 & 3.6 & 0.6 & $\mathbf{9 9 . 9}$ \\
\hline Employees* & 6.0 & 21.9 & 21.6 & 19.5 & $\mathbf{6 8 . 9}$ \\
\hline Sales revenues & 7.4 & 14.4 & 19.7 & 18.1 & $\mathbf{5 9 . 6}$ \\
\hline Export & 5.9 & 5.5 & 10.3 & 13.5 & $\mathbf{3 5 . 3}$ \\
\hline Value added & 6.0 & 10.9 & 16.4 & 18.7 & $\mathbf{5 2 . 0}$ \\
\hline Equity & 8.9 & 11.9 & 14.6 & 15.8 & $\mathbf{5 1 . 2}$ \\
\hline
\end{tabular}

: * including the financial sector

ures, MoET calculations for the res

\title{
VEZETÉSTUDOMÁNY
}


The Hungarian Central Statistical Office (HCSO) adopted the new European method in 2005 thus decreasing substantially the number of operating enteprises. An enterprise is now considered to be operating in a given year if it had sales revenues or had at least one employee. In 2004 the number of operating enterprises was 871,956 and 708,307 according respectively to the old and the new methodology (MoET, 2007a p.129-131.; Strategy, 2007; Völfinger, 2005).

While microenterprises (with less than 10 employees) employ a higher share than in other transformation countries, except Poland, and EU-15 countries, the employm ext she of small (20-49 enployes) the employm and medilun sized enterprises (50-249 employees) is lower tha no oner con SMEs compared to the inhabitants and the employment share of SMEs remains higher in Hungary an other transformation countries (with the relevant exception of Slovakia and Romania) than in EU-27 on average and is similar to the structure in the Southern EU member countries (Eurostat, 2008; OECD, 2008c).

Both sales revenue per enterprise and value added per employee are a fraction of the EU average in both relative (Table 2) and absolute terms (Table 3), with somewhat better performance only for small enterprises in sales revenue. Therefore, it is inevitable that labour cost cast per wie aded is high is Hungary, except in the case of miche underground econony may influence the explanatory

Enterprises in Hungary (2005) compared to the EU-19 (2003) (EU-19=100)

\begin{tabular}{|l|c|c|c|c|c|c|c|}
\hline & & Micro & Small & $\begin{array}{c}\text { Medium- } \\
\text { sized }\end{array}$ & $\begin{array}{c}\text { SME } \\
\text { together }\end{array}$ & Large & Total \\
\hline Average size & HU/EU-19 & 59 & 107 & 102 & 61 & 83 & 58 \\
\hline Sales revenue per enterprise & HU/EU-19 & 17 & 47 & 31 & 21 & 30 & 19 \\
\hline Value added per employee & HU/EU-19 & 17 & 19 & 15 & 17 & 20 & 17 \\
\hline Labour cost per added value & HU/EU-19 & 71 & 111 & 135 & 103 & 119 & 109 \\
\hline Proportion of export in sales revenues (\%) & HU/EU-19 & 122 & 92 & 106 & 108 & 178 & 135 \\
\hline
\end{tabular}

Note: EU-19: 15 Member States + Iceland, Liechtenstein, Nor-

Source: SMEs in Europe, 2003, Observatory of European SMEs, No. 7, calculations based on data provided by APEH

More than looking at comparisons with richer market economies, for countries still undergoing some relevant transformation it may be important to look developments. The data show that a substantial part of Hungarian SMEs is weak also under this heading.
Hungarian enterprises compared to EU-25

Table

\begin{tabular}{|l|c|c|c|c|c|}
\hline & Micro & Small & Medium & $\begin{array}{c}\text { SME } \\
\text { total }\end{array}$ & Large \\
\hline $\begin{array}{l}\text { Number of } \\
\text { enterprises }\end{array}$ & 1,03 & 0,60 & 0,64 & 1,00 & 1,00 \\
\hline $\begin{array}{l}\text { Number of } \\
\text { employees }\end{array}$ & 1,20 & 0,89 & 0,98 & 1,05 & 0,89 \\
\hline Sales revenues & 1,09 & 0,98 & 0,97 & 1,01 & 0,98 \\
\hline Added value & 0,84 & 0,85 & 1,03 & 0,90 & 1,13 \\
\hline
\end{tabular}

A MoET (2007a) survey distinguishes three different groups of SMEs in terms of performance and this pattern has been stable since the late 1990s: a) fastrowing enterprises: this group includes some 15\% SMEs whose yearly growth exceeds $20 \%$, are often part of groups or value chains and networks, produce ntermediate goods or business services, are active in public procurement tenders and innovative and active in foregn mankets, are endowed with important tive in foreign markets, apital, make intensive use of fecialized professional services, and of bank credit (they repof the SME population, have low but positive performance and low qualification of their

Table 2

entrepreneurs/managers and employees, and produce mainly for the retail market without using bank credit, except microcredit and mutual guarantees; c) laggard enterprises include the $15-20 \%$ of isolated small enterprises and enterprises run by marginal businessmen (elderly, social and minority businessmen) with negative and declining performance, selling their products to the final consumers and making no use of external finance and services.

VEZETÉSTUDOMÁNY

\section{Problematic issues}

Policies outcomes have been modest so far due to various reasons. First, programmes are usually episodic and uncoordinated. Second, they have failed in fostering the entrepreneurs' interest (particularly young and educated ones) to specialise, modernise and promote the growth of their enterprise. Third, nearly all programmes show time inconsistency and they are discontinued after relatively short time. Fourth, many programmes depend upon donors and do not involve the beneficiaries' responsibility, e.g. by means of cofinancing. Fifth, the donor typically is not involved in following the outcome of the investment after the support is over: the relation between the donor and the beneficiary is usually formal and short-lived.

A sixth general problem is the lack of evaluation culture. Evaluation of policy programmes is important in order to asess their efficacy and adjust then a posibilites. Evalution shold follow a standardised approach in order to provide policy-nakers, experts and the public with technically grouked and cond the public with technically grounded avoid the well-known self-selection and committee selection problems ${ }^{5}$. Evaluation in Hungary is only moving through the first steps, an evaluation culture is still lacking, and the insufficient continuity of the programmes prevents assessing themselves: time is not enough for seeing the impact of the programmes on the beneficiaries. Evaluation at the level of policy makers is still more formal than substantial, and only few programmes have been evaluated. Existing evalufew programo have been ation is mumber of interveris sibly disting (tyshed by size class - applied to and received funds from individual programs), jobs created and funds spent (possibly broken down by size class of enterprises and aim of the application). Typically the results of the programmes are not analysed again what would have happened without the programme.

To address this situation the government approved, on 10 October 2007, the Strategy for the Development of Small and Medium-sized Enterprises (2007-2013) (Strategy, 2007) to pursue "the improvement of the economic performance of small and medium-sized enterprises" as part of the implementation of the National Strategic Reference Framework of Hungary for the period 2007-2013. Another important milestone in the development of a national SME strategy has been the approval by the European Commission of the Economic Development Operational Programme 2007-2013 (MoET, 2008), a programme under the Convergence
Objective providing for important financial support ( 2.9 billion, of which some $€ 2.5$ billion are contribut(d) bU) among other things to upgrade the SMEs competitiveness. The main objective of the Programme is to increase the value added and the jobs created by SMEs and their productivity by, among other things, facilitating SMEs access to finance and promoting the development of the business environment.

SME policy and programmes are designed with a long term perspective, aimed at ensuring entrepreneurs a more stable and predictable regulatory and policy framework. However, while the Strategy pays attention to the woply side i.e actions and services provided to SMEs, iteves less effort the dervices it devotes less effort to the demand side, where many of phe's problems onginate and subsist. For instance, emphasis is put on the various instruments to ease SMEs financing constraints, but much less so to the critical issue of how to increase the willingness and opportunities of entrepreneurs to ask for and use efficiently financial resources. Regional differences in SME characteristics and constraints are also a crucial component that should be considered when assessing the proper policy design. With the exception of EU funded projects, SME policy remains centralised in Hungary.

The 2007 SMEs Strategy promises to initiate a new phase of evaluation in SME policies in Hungary: it includes monitoring and takes commitment for an interim assessment of the outcome of the Strategy (Strategy, 2007) by quing them according to the set of tare and distinguishing targets, comprehensive objectives, horizoce (strategic However objectives are Cire cisely specified. For instance, the strategic target "increasing the economic performance of small and medium-sized enterprises" is expressed as the increase of the ratio of gross value added produced by SMEs from the current $52 \%$ to $55 \%$ by 2013 , without specifying the conditions, e.g. whether this will be the outcome of growing numbers of SMEs or growth of individual SMEs. This incompleteness makes it impossible to assess whether a certain outcome (or failure) may be ats. Further, the Strategy may lack time continity due to the implementation of new policy priorities and instruments since late 2008.

\section{Fostering SME Competitiveness}

Many SMEs policy programmes focus on the size of enterprises, thus failing to consider whether their activity has the potential to increase the competitiveness of enterprises and consequently generate economic

\section{VEZETÉSTUDOMÁNY}


growth. Hungarian policy-makers are apparently aware of this problem and have become attentive to policies supporting SMEs competitiveness. However, variou flaws still remain in policies. I shall consider the folowing critical aspects: a) the business environment; b) human resources; c) access to financing; d) barriers to SMEs access to international markets.

a. The business environment. Entrepreneurs in Hunburdens as the single most important factor impeding firms operations (Table 5, MoET, 2007a), although this rating has decline tax system has bed improvents inclu with additional easing for lower tax base, and the introduction of the simplified entrepreneurial tax. Socia security payments ${ }^{6}$ remain particularly high for labourfirms to make use of tax allowance. The fiscal burde represents $38.6 \%$ of Hungary's GDP, a rate lower than the EU-25 average (40.9\%), but significantly higher with low tax moral, which places Hungary at a low $111^{\text {th }}$ in the overall ranking of World Bank - Doing Busines (WB-DB) 2009 and 11 ${ }^{\text {th }}$ in EECA region (Table 4).

Table 4.

The Hungarian economy

in the World Bank Doing Business Rankings, 2009 (2008 in parenthesis)

\begin{tabular}{|l|c|c|}
\hline \multicolumn{1}{|c|}{ Ease of... } & $\begin{array}{c}\text { Doing Bu- } \\
\text { siness 2009 } \\
\text { (2008), } \\
\text { total rank }\end{array}$ & $\begin{array}{c}\text { Doing Busi- } \\
\text { ness 2009 }^{*} \\
\text { EECA rank" }\end{array}$ \\
\hline Doing Business & $41(50)$ & 7 \\
\hline Starting a Business & $27(72)$ & 6 \\
\hline Dealing with Construction Permits & $89(90)$ & 12 \\
\hline Employing Workers & $84(83)$ & 12 \\
\hline Registering Property & $57(98)$ & 13 \\
\hline Getting Credit & $28(25)$ & 10 \\
\hline Protecting Investors & $113(110)$ & 23 \\
\hline Paying Taxes & $111(109)$ & 11 \\
\hline Trading Across Borders & $68(49)$ & 10 \\
\hline Enforcing Contracts & $12(13)$ & 2 \\
\hline Closing a Business & $55(56)$ & 6 \\
\hline
\end{tabular}

Note: Doing Business 2008 rankings have been recalculated reflect changes to the methodology and the addition of three new countries.

** Eastern Europe \& Central Asia, 27 countries

Source: The World Bank Group, Doing Business gary continue to identify high tax and social security rating has declined between 1997 and 2007 as the the intensive SMEs, which find it more difficult than large than in Visegrád countries. The tax system compares

Variability and unpredictability of economic regulation are perceived to be the second main obstacle to the operation of enterprises. They are particularly problematic for small enterprises, which lack internal capacities to deal with it and may have to use costly external support services. Change of regulation has been in part the result of compliance with the acquis communataire, in that regulation regarding the SME sector was harmonised following EU membership. However, unpredictability has been primarily the outcome of domestic changes.

According to the European Commission, in the EU25 administrative burdens of entrepreneurs make up on average 3.5\% of GDP (Strategy, 2007). MoET timates that direct burdens to Hungarian entrepre (comprising data provision to the public administrion and other burdens related to public adc aninistration cedures bus ans related to public administration procedures) may amount to $4.5-6.7 \%$ of the GDP. About $1.5 \%$ of these stem from EU obligations, while a larger part is generated by the Hungarian regulatory and public administration environment.

According to WB-DB (2009) rankings, Hungary scores $41^{\text {st }}$-out of 181 countries as concerns "ease of doing business", and $7^{\text {th }}$ in Eastern Europe \& Central Asia (EECA) (Table 2). However, while starting a business witnessed an impressive improvement in 2009 , dealing with construction permits remains a serious obstacle to withe fortacle to SME for problematic although not satisfactory. Eficient bankruptcy laws and procedures are important factors for a conductive business environment. Although according to WB-DB Hungary ranks 12th in enforcing contracts and $2^{\text {nd }}$ in the EECA region, bankruptcy procedure is harsh for both debtors and creditors, and does not facilitate recovery particularly for small enterprises. Companies in trouble have maximum 150 days to negotiate with their creditors and recover. As a consequence, only 8 enterprises restructured in 2006 out of 14933 enterprises which went through bankruptcy procedures, and 9439 came under liquidation. This outcome can be ascribed to various factors including: increasing defatis on pay to va foults credit inuts credit ins evaluation cilture in domestic SMEs. The new Bankruptcy Act should unify to one procedure the presently separate bankruptcy and liquidation procedures and shorten the time needed for liquidation (Strategy, 2007; BD, 2007; Simon - Turóczi, 2007)

Although property rights are in general well-defined and protected, other aspects related to this issue need to be clearly set. Registering property has been substantially improving but is still problematic (WB-DB scores

VEZETÉSTUDOMÁNY are 57 on 181 and 13 on 27 respectively in the overal and the EECA indexes), and even more problematic is the protection of investors (scores are respectively 113 and 23). Only $65 \%$ of Hungarian enterprises are aware of industrial property rights protection issues and $40 \%$ are involved in their protection through means such as trademarks, patents, and licences.

Over the last decade, information and communication technologies (ICTs) have opened up ever increasing opportunities for SMEs, allowing the advantages of small scale to be combined with economies of scale and cope through networking among firms and w scope through netwith other actors such as unersitif In recent years he among Hun levels of technical sophistication (i.e. using a computer and holding an internet connection). Hungary fal behind the European average with respect to: i) the use of more sophisticated technologies (broadband access), although not behind most new EU member countries; ii) the weight of security in business decisions; iii) the share of companies using digital signatures; and iv) the use of electronic commerce by Hungarian enterprises (less than half the EU average, the last position in the EU). Even worse is the gap in the use of more sophisticated IT and e-business solutions, in which sophisticated distance very weak in the share of enterprises having internal company processes and external integrated company processes. In all these aspects SMEs fare considerably worse than large firms (e.g. in broadband internet penetration, the gap is close to 50\% - MoET, 2007a), wit the partial exception of medium-sized companies.

Further development of E-government is important because it can substantially improve the productivity of the public administration, significantly decrease transaction costs of enterprises, and reduce the discretionatity of public administrations, thus improving the quaity of compliance with rules and accountability. Th contributes to create a more predictable enviry. This contributes to for enterprises. E-government services completely accessible electr. E-golly for higher than the EU average (36\%), due to the substantial improvement during the past few years. Howeve in the case of enterprises, Hungary ranks only $21^{\text {st }}$, significantly behind the European average (MoET, 2007 UN, 2005)

b. Human resources, motivation, and networking. Managerial weaknesses are a key cause of (small) bus ness failure and a shortage of skilled workers is a barrier to innovation. Together with regulation, human resourc- es are apparently and important weakness of Hungarian SMEs. Traditional formal education is good, but country ranks below European average concerning life-long learning and the share of students in the technical and natural sciences. Most non-corporate R\&D personnel is employed in higher education institutions. Training, education to entrepreneurship, e-learning and distance learning and $R \& D$ human resources are all at rather low levels in SMEs. Along with being at low level, $R \& D$ also has excessive concentration at (mostly arge) enterprises with foreign ownership: these concentrate nearly $80 \%$ of corporate research, while only -3\% of SMEs are in covative pioners and $20-22 \%$ are pioneers and $20-22 \%$ are

The willingness to start-up companies has significantly deteriorated in the population (CSO, 2006 GEM, 2008). ${ }^{8}$ There may be different reasons for this trend, including that the post-transition years of enthusiasm and great opportunities are over. However, this could also be related to the fact that the best motivated, skilled and educated people are attracted by the working conditions and salaries offered by multinational subsidiaries operating in Hungary. Existing SMEs show high concentration in more traditional branches, in particular real estate trading and renting traditiona business support services, trade, construction industry. Although this may be an answer to metion industry. Al demand, . ask, knowledge and technology-based competitive industries and prefer those that require lower capital intensity, guarantee rapid returns and do not require par-
ticular technical skills.

As in many OECD countries, there is also an increasing trend in SMEs to specialise in their core business and subcontract some operating functions (accounting, marketing, legal, technical, IT and other services) to other specialised SMEs. This trend may be associated to the labour market regulation and lack of flexibility which can have the detrimental effect of raising the risk associated with increasing employment: according to WB-DB overall and in EECA respectively.

There is also an increasing trend to networking that by now involves more than half of SMEs, (MoET $2007 \mathrm{a}$ ). About $57 \%$ of all enterprises participated in 005 in some form of formal or informal cooperation with other enterprises (counselling, borrowing tools, machines or money, acquiring business, etc.). Of these $17 \%$ are engaged in formal cooperation (joint purchase, sales, production). However, most of these are soft forms of networking and production networking is scarce. A promising although limited development is

\section{VEZETÉSTUDOMÁNY}


the increase of ownership cross-holding, which is pulling cross-investment. This is leading to greater corporate concentration and may strengthen the enterprises resource base and performance.

A considerable effort was performed in the pas years to set up a network of industrial parks and other infrastructural devices such as regional university knowledge centres, which by now have a fair situation. Although they may be important tools for solving the enterprises location problems and facilitate business cooperation, their effect is modest: there have been few spin-offs and the infrastuclure suppo has remained weak in general (Strategy, 2007).

c. Access to financing. Although Hungarian SME have been the only net job creators over the past 15 years, their performance has been modest in relation with the growing amount of resources, including foreign and EU resources, spent to support this sector. Moreover, less than 4\% of SMEs benefited from deve opment programmes, with the lowest rate in the smalest size classes. Before the 2008 crisis financial need were ranked low among the impediments to the grow

ome firms, parent companies. However, the inability or unwillingness to access external finance is critical for the development of these SMEs (McIntyre - Dallago, 2003). Since 1999 financing issues have become increasingly less problematic, reflecting the fact that commercial banks and savings cooperatives increasingly served SMEs with new loan products and services. In the WB-DB ranking Hungary gets a fair 28 in the overall ranking and 10 in that referring to EECA for getting credit. The EBRD index of banking sector reform is in fact 4.0 in 2008 , as it was in 2001 , and that of non-bank fincial institutions improved in the same period in the same peniod from 3.7 to 4.0. This puts Hungary the Domesic cedil to tries. Domestic credit to the private sector compared to GDP improved from $30.9 \%$ to $54.6 \%$ leaving the other central European countries at distance. Also, the government took positive steps to ease the traditional SME aversion of large banks, particularly with the multi-pillar special credit system set up in 2003 and jointly operated by various credit institutions and organisations.

Factors impeding enterprise growth in Hungary

\begin{tabular}{|l|c|c|c|c|c|c|}
\hline & $\mathbf{1 9 9 7}$ & $\mathbf{1 9 9 8}$ & $\mathbf{1 9 9 9}$ & $\mathbf{2 0 0 3}$ & $\mathbf{2 0 0 5}$ & $\mathbf{2 0 0 7}$ \\
\hline High tax and social contribution liabilities & 84 & 78 & 73 & 74 & 72 & 77 \\
\hline Unpredictability of economic regulation & 62 & 58 & 53 & 58 & 55 & 63 \\
\hline Strong competition & 53 & 57 & 61 & 61 & 61 & 56 \\
\hline Shortage of orders & 48 & 45 & 52 & 45 & 48 & 45 \\
\hline Unfair competition & 46 & 44 & 44 & 47 & 48 & 45 \\
\hline Delayed payments of customers & 30 & 31 & 30 & 32 & 34 & 35 \\
\hline Shortage of capital & 40 & 37 & 37 & 34 & 32 & 31 \\
\hline Other inhibiting factors & 19 & 20 & 17 & 16 & 13 & 19 \\
\hline Procurement difficulties & 14 & 16 & 16 & 17 & 16 & 13 \\
\hline Obsoleteness of existing capacities & 17 & 19 & 17 & 17 & 13 & 12 \\
\hline Shortage of loans & 27 & 26 & 26 & 20 & 15 & 12 \\
\hline Shortage of labour & 9 & 9 & 9 & 12 & 8 & 9 \\
\hline Source: MNDE (2008), p. 159. & \multicolumn{7}{|l|}{} \\
\hline
\end{tabular}

of enterprises (Table 5). This may be due to both credit aversion by entrepreneurs and to banks targeting more developed clients, together with the absence of significant programmes for potential entrepreneurs (JEREMIE, 2007)

The Hungarian experience - similar to that of other former transformation countries - is that lack of financing is not an important obstacle to the creation of small firms, which rely on informal sources or, for

The limited financial penetration is due to different factors: ignorance or worry of many entrepreneurs of the existing possibilities and their features and fear or inability of growing; insufficiently developed guarantee and insurance system; weak reputation and trus preventing the matching of demand and supply; fear to weaken or jeopardise the owners' control over the enterprise. These problems require a broad spectrum of financing solutions and education of entrepreneurs.

VEZETÉSTUDOMÁNY
Other financing instruments show a similar pattern: rapid development, inability to attract the most enterprises, and overall modest effect (JEREMIE, 2007, MoET, 2007b). The importance of microfinance has been rapidly decreasing, while banks have preferred to target stronger clients. There is currently no significant programme targeting potential entrepreneurs. Perhap the most successful among financial instruments has been leasing, whose amount has increased threefold between 2000 and 2005 reaching $5.4 \%$ of GDP. However, $80 \%$ of transactions are related to vehicles. Factoring is of till highly undereveloped similarly to buctoring is still highly unde angels and venture capital: expanding busin. stage and weak in the start-up stage. Credit guarantee for SMEs is improving but still insufficient and the majority of guarantee operations relate to loans extended to microenterprises.

d. Access to international markets. Although nearly two thirds of exports come from large enterprises (table 1), primarily from the subsidiaries of multinational companies, the propensity to international trade of Hungarian SMEs is generally high in internation comparison, particularly in the case of microenterprises (Table 2). In most countries barriers involve critical SMEs aspects: capabilities, finance and access (OECD, SMEs aspects: capabilities, finance and access (OECD, 2007). Increasing export is prominent among the Straegy objectives, which foresees a $2 \%$ increase over 2005 of the SMEs export participation, although other form of internationalisation do not receive attention. Increas ing SMEs international activity will be possible only Hungary is able to remove part of the barriers to foreig trade that for the time being rank the country only 68 in the WB-DB general index of trading across borders and $10^{\text {th }}$ in the EECA index.

Top barriers include inadequate quantity of, and untrained personnel for internationalisation, and limited or problematic access to foreign markets. The latter includes limited information to locate and analyse markets, and identifying foreign business opportunities and barriers belonging in the business environgent, like unfamiliar exporting procedures and paponment, like unfaniliar exporting procedures and paperwork. Working capital to finance exports is apparently suffcient for high-growth SMEs, but is an important barrie for more traditional enterprises.

It is interesting to notice that in addition to the ad vantages deriving from EU integration, Hungary has a information, knowledge and relational advantage in the neighbouring countries in regions inhabited by Hungarians. This is apparently a factor easing also capabilities barriers, particularly those related to the inability to contact potential foreign costumers.

\section{VEZETÉSTUDOMÁNY}

The international crisis: A watershed?

SMEs are found to be important in cyclical downturns and recessions (Erixon, 2009a, 2009b; Vandenberg, 2009). In fact and while crises are usually caused by the financial sector or large enterprises, SMEs are more resilient since they are more flexible, more oriented towat the domestic economy and to services, more f ily based and less prone to downsize enploymore family based and less prone to downsize employment. However, this greater dependence upon domestic demand and the limited amount of internal resources make SMEs more sensitive to the events in the domesic economy in both downturns and recovery. Since countercyclical measures tend to support domestic demand, these have a disproportionate effect on SMEs.

The international financial crisis is rooted in a combination of factors common to previous financial crises and some new factors, including deficiencies in financial regulation and architecture. Of relevance is the fact that financially integrated markets, while offering many benefits, can also pose significant risks, with large real economic consequences (Claessens, 2010). The crisis, which has had important direct budgetary costs, has wen has been particularly aggressive in Hungary: the country was the first EU menter loan package to the IMF, the European Union and the World Bank to avoid sovereign default and currency $\mathrm{col}_{-}$ lapse in October 2008. Reasons for this vulnerability include irresponsible and inconsistent fiscal policy stance in particular since 2001, high debt, domestic monetary policy and the nature of the country integration into the international financial system (Andor, 2009).

Poor fiscal policy quality (Staehr, 2010; Winkler, 2010), policy mistakes and the lack of structural reform in Hungary led to a record deficit, rapidly increasing debt ${ }^{10}$ and a serious drop in competitiveness by 2006. The 2006 reform programme, including the Strategy discussed herewith, reached some inccess and avoided the immedithe immedi列 lems. Particularly problematic are the structural features and weaknesses of the economy: considerable foreign trade exposure, weak export structure and performance, particularly by the domestic sector, significant external debt. Foreign ownership of banks, that was found to contribute to financial vulnerability (Popov - Udell, 2010), represents a slight advantage for Hungary, thanks to the stronger position and higher capitalisation of domestic banks (particularly OTP). However, the tendency of foreign banks to lend in foreign currency (Stein, 2010) has been particularly great in Hungary, which increased financial instability of consumers and local SMEs in the wake of the forint rapid devaluation (by $40 \%$ against the Euro between August 2008 and March 2009). 
Even more important have been the crisis indirect effects on the real economy through depressed revenues and spending, lower economic growth and infor SMEs have been consequently important. The inreflected in the depressed mood of the business community that continues through $2010 .{ }^{11}$ The crisis has put a stop to a growth process that was based on flow of external funds and internal consumption largely funded through loans. The drop of the value of real estate, by far the most import far the most important asset in households' portfolio ened the value of the most typical collateral that SMEs ened the value of the most typical collateral the

The effect of the crisis on SMEs has been generally The effect of the crisis on SMEs has been generally
harsh (Hodorogel, 2009). In most of the 29 countrie harsh (Hodorogel, 2009). In most of the 29 countries reviewed by the OECD, including Hungary (OECD, 2009; OECD-Intesa, 2009) SMEs report a severe decline in demand for their goods affers from country the magnitude of the shock differs from country bankruptcies and increased payment delays - which add to the endemic shortage of SMEs' working capital and their decreased liquidity - further strengthen fall in sales. SMEs adaptation to the crisis has been apparently contased by the baks' policy. Indeed, the significtly wors to financial shock. In fact, evidence suggests that cred has decreased as a source for financing SMEs inves ment projects and SMEs' demand for working cap tal and short-term loans has been reduced, althoug not as dramatically as for investment purposes. Banks have tightened lending policies in terms of guarantees, collateral and amounts, although not exclusively towards SMEs, and in some countries have substantially increased the cost (and spreads) of credit to all their increased

SMEs response include: a. cost-cutting, particularly of the wage bill, to restore profitability and adjust production to lower demand; $b$. search for additional sources of liquidity (e.g. extending own payment delays and reducing or suppressing dividends); an c. postponing investment and expansion plans. The governments' anti-crisis packages have tried to ease SMEs' financing problems. These packages include: a. supporting sales and working capital through export ter payment discipline by governments; b. enhancing SME's access to liquidity through bank recapitalisation creased unemployment (Staehr, 2010). Consequences ternational crisis has thus been particularly severe, as parently contrasted by the banks' policy. In been apconditions on access to bank credit have generally and mutually reinforcing shocks: a demand slump and credit and insurance, tax reductions and deferrals, bet-

and most often expansion of existing loan and credit guarantee schemes; and c. helping SMEs investments by means of grants and credits, accelerated depreciation, and $\mathrm{R} \& \mathrm{D}$ financing.

In Hungary, the oversized state and internal consumption generated sustained external financing needs and demand for credit. Growing exposure and increasing real interest rates in the domestic market led the majority of companies and households to incur their debts in foreign currencies: retail loans in foreign currencies increased from $0 \%$ in 1997 to $18 \%$ in 2003 and $70 \%$ in 2008. In a 2009 Word Bat $18 \%$ in 2003 and vey, in Hos. In a 2009 Word Bank cross-country surtic in Hung 52.4 percent of firms - mostly domestic oreted - we found to have an average of 67.3\% of foreign-currency denominated debt (Correa - Iootty, 2010). In spite of marked inprovenent of the financial situation since 2006, the external vulnerability of the economy remained acute and the crisis further exacerbated it (MEH, 2009; MNB, 2009).

The crisis has impacted on a country in difficult situation, including low employment rates and prolonged recession, high dependence on exports and high external debt, being a substantial part of the latter in foreign currencies. In the effort of adjusting to the crisis the government implemented a set of crisis management ground for implementing a new comprehensive and long-term strategy pursuing short term mitigation of the crisis, including assuring budget equilibrium and supporting employment, and long term reforms (MEH, 2009; OECD-Intesa, 2009). This new strategy addresses four mutually reinforcing structural problems, which reduce significantly the growth potential. These are: a) the obsolete state with high expenditures, and excessive level and inadequate structure of redistribution; b) low employment; c) the weak structure of the real economy; and d) high financing needs.

The government took determined policy measures in April 2009 to decrease the economy's vulnerability and April 2009 to decrease the economy 's vulnerability and chese incal uses for fick stabilization (including shot a measnity leave, incer nity leave, increased pension age, changes in the tax system and social security contribution, public works programmes, job protection measures and reform of unemployment benefits). However, in spite of determined action and the success in reaching greater stability of the domestic banking sector (MNBb), "Hungarian economic recovery is likely to lag behind that of developed countries and the economies of Central and

VEZETÉSTUDOMÁNY
Eastern Europe on account of persistently weak dome tic demand" (MNB, 2010a).

The 2009 economic strategy (MEH, 2009) is im plemented in two phases: a) managing the consequences of the world economic crisis and preserving a balanced budget on the short term together with increasing the level of employment and creating the basis for economic growth; and b) restructuring public finances, improving the supply of and access to public services and various structural measures in the longe term. The first phase comprises five aims, including the support to developing the economy and infrading ture, which is highly relevant for SMEs. An importan ture, which is aim is establishing a work fiendly tax regime by substantially decreasing taxes and social security contributions on wages (by 7\% in two years). Fiscal balance is pursued through transferring taxation to other items, including increasing value added taxes, excise taxe, property taxes and fighting tax evasion and avoidance. Other aims include developing a targeted social net encouraging work; a stable and predictable pensio system; and establishing a cheaper state and a new policy making.

International action, the international financial support package to Hungary, and the measures taken by vulnerability (IMF, 2009, MNB, 2009). However, the vulnor economy is in serious recession (MNDE, 2010a), an
this jeopardises the financial stability and solvency of this jeopardises the financial stability and solvency of the economy (Barrell - Holland, 2010). In fact, banks liquidity and solvency risks are still high. Measures supporting bank lending have therefore received attention and authorities' and parent banks' interventions have reduced liquidity risks.

The deteriorating macroeconomic environment and the increasing risk aversion of banks are diminishing credit demand from and supply to the corporate an household sector. The reduction is more pronounced for SMEs than for large corporations and SMEs situation is particularly fragile, since they have a higherthan-average proportion of short-term loans. However, SMEs benefit the most from domestic and Europea refinancing programmes.

Taxation of enterprises changed and became more favourable to SMEs that invest and increase employment and less favourable to larger enterprises (APEH, 2010). Indeed, while corporate (profit) tax rate increase to $19 \%$ effective from January 2010 and foreign associations have a corporate tax rate of $30 \%$, up from the previous reduction to $16 \%$, most credits and allowances reducing the corporate tax base were cancelled, except investment benefits (development reserve, investment benefit for SMEs, accelerated depreciation). Contributions payable by employers were reduced from $32 \%$ to $27 \%$. The government foresees that taxation of enterprises will decrease overall by some HUF 40 billion (approximately $€ 135$ million).

The government has introduced four new programmes since November 2008 and has eased the conditions of some existing ones in order to mitigate the funding problems faced by SMEs (MNB, 2009). The new support is in two forms: three new programmes supporting the banking system in refinancing corporate loans, financed mainly from EU sources (Új Magyarország Working Capital Credit Program, SME Credit Program, Venture Capital Program), and measures providing subsidies on interest or guarantee scheme through the state budget. The overall shortterm support is HUF 140 billion ( $€ 480$ million) corresponding to $10 \%$ of the total volume of SME loans maturing within a year. The overall provision of new funds amounts to HUF 225 billion ( $€ 780$ million). ${ }^{13}$

The new economic policy aims also at introducing some important structural measures aimed at strengthening the Hungarian economy so to support post-crisis development. Among these structural measures the development of SMEs is prominent. The main aim is upgrading the large part of SMEs that is presently stagunt and serving prim the domestic market. The objective is not new in that it consists of making these mest market, particularly in the branches where Hungary has a comparative advantage and where jobs can be reated.

To this end, the government intends to use two main sets of instruments: assisting financially the enterprises' market entry and reducing administrative burdens. Instruments span from action aimed at improving the context (e.g. international diplomatic effort to promote exports, cutting bureaucracy and regulation, faster procedures in lawsuits, electronic payment of orders, support to research and development, security of energy supply, development of infrastructure) through finge cials ipport (cedit programes credit insurance) to real services (public procurement programme, export promotion, electronic registration of companies in one hour, simplification of site authorisation). Noteworthy are public procurement programmes and reduction of administrative burdens. As to the former and in compliance with the EU Small Business Act, SMEs with less than net HUF 1 billion revenues a year $(€ 3,4$ million) use a simplified procedure supported by the contracting authority starting rom 1 July 2009. The government also decided to re- 
duce the administrative burden of the enterprises arising from national regulation by at least $25 \%$ by 2012 . The Government also worked out and is implementing
programmes aimed at fostering both vertical and horiprogrammes aimed at fostering both vertical and horizontal integration of SMEs. A programme supporting SMEs suppliers to large companies in the processing industry has started in February 2008 with EU funds. A competitiveness pole programme encouraging networking and cluster formation and development has also been launched.

Firms in general and SMEs in particular have responded fairly to these measures. Indeed, according to a World Bank cross-country business survey in Eastern Europe $^{14}$ released at the end of 2009 Hungarian firms appear to be among the least affected by the financia crisis (Fodor - Poór, 2009; Ramalho et al., 2009; WB, 2009; Correa - Iootty, 2010). The survey found that the major effect of the crisis is a drop in demand (lowe in Hungary than elsewhere) which has caused a drop in employment ${ }^{15}$ affecting mostly permanent employees and has pushed firms to use more internal fund to finance their working capital and postpone investments. The latter effect has been important particularly in Hungary $(+4 \%)$, evenly spread across all firm sizes and industries. Supply-side effects, and particularly so access to credit have appeared to be generally less relevant than duing previos crises, but less so for a larer vant the con household and corporate debt - particularly the forme including SMEs debt - has fallen back to 2008 level up to mid-2009 and then stagnated thanks to the significant appreciation of the forint (MNDE, 2010b).

Although in general the percentage change in sale is inversely related with the size of the firm, in Hungary medium-size firms has shown a slightly smaller drop in sales than large firms and also capacity utilisatio has witnessed little change $(-5 \%)$. An important idosyncrasy also exists in employment: while large firms significantly reduced permanent employment (partic larly so firms in domestic ownership), SMEs increased their permant employment although freezed wages. Overall, fewer fits are relly in fince compared to the other countries.

\section{Conclusions}

SMEs have great potential in Hungary and have reache fair results. Their importance in the economy, their jo creation and innovation potential justify special at tention and care. The perspectives of the Hungarian economy depend to large extent upon the competitiveness of SMEs, which account for much of employment and important parts of production and exports. In spite of internal and external constraints, progress has been made in recent years in policy-making and achievements related to SMEs. The goal of upgrading SMEs and strengthening their contribution to the economy has acquired important position in the government agenda and policy goals. While progress took place, there are also problematic areas and in some cases drawbacks have happened. The international crisis has exacerbated drawbacks.

SME policies have been neither cost-effective nor sufficiently stable in time or appropriate to foster Hunsarian SMEs' conp gn. Policies cove my. Policies have been so far more targeted to existing SMEs and are lacking the full entrepreneurial dimension necessary to foster innovative and internationally comperitive SMEs. Inportant issues such as awareness and capacity building, opportunity recognition and utilization have been overlooked. As a consequence, most SMEs have created jobs but hardly innovated and become competitive. This is the challenge for the years to come.

The pre-crisis Strategy denotes a serious effort in overcoming the main problems afflicting the sector. It affords a detailed and realistic situation analysis and build upon it the detailed formultion of a new strategy for the development of strat( enter trepreneurship satisfactorily. Through the Strategy the government placed SMEs policies in a perspective that is broader, more detailed, better defined and better coordinated both internally and with other policy areas. It also avoided in its design the danger of interfering with the market by pursuing healthier cooperation between the public and private sectors. However, problems remain open and questions remain unanswered or the answer is short to the reality.

The new post-crisis development strategy is apparently wise in that it does not concentrate exclusively on crisis management and advances further in a balanced direction. Indeed, it aims at making the establishment and management of new enterprises easier and cheaper, thus hopefully reviving Hungarian entrepreneurial attitudes and making existing SMEs stronger and more competitive. However, two caveats are worth stressing.

First, although the strategy includes several wise and sound aspects, it still requires more precise priorities. It includes too many goals, although these are desirable in themselves. Second, the danger is still up that the new strategy can be a new chapter in the old problem of policy instability and unpredictability: although motivated by sharable and desirable aims, it also in- cluded components (e.g. in taxation policy) that invert previous goals. Whether it will actually result in an important step forward will depend upon the long-run consistency of its implementation, the careful definition of priorities and the effective cooperation between government and the business sector.

The international crisis has made the heavy indebtedness in foreign currencies and the budget deficit difficult to manage. Therefore, macroeconomic policies have taken the lead in the government's concern and priorities. However, the forint depreciation - particuprirly until raw meterials remined relatively chap, harticularly un law some a Tantage primarily for SMEs, supporting the expot. This peisod was shot, and was followed soo by substantial font appreciation, that has had the merit of decreasing the burden of debt in foreign currencies.

The country has been recovering from a serious financial crisis with fair results, including the compar tively fair resilience of SMEs, overcoming a potentially very risky situation, and is now confronting the real effect of the crisis. The government has been inevitably led to pay absolute priority to the macro-stabilisation of the economy. Amidst these urgent and pressing goals the SME strategy implementation and even the issue of weak SMEs competitiveness has been lost of sight. This is understandable, although it may have negative longrun consequences. It is to be seen whether this neglect has been a short-term price paid to more urgent need that will be overcome soon with stronger determination. The country serious vulnerability, that the crisis revealed beyond doubt, requires that the issue of SME competitiveness is placed again and with stronger determination at the centre of the policy stage.

\section{Footnote}

This research was funded by the Autonomous Province of Trento, as the sponsor of the OPENLOC research project under the call for proposals "Major Projects 2006". I thank Jacopo Sforzi for support in the research.

The share of high-tech and medium-high-tech exports increased remarkably in various countries, including Hungary. However, ( 26 December 2009: p. 7.).

http://www.simondyda.net/2009/05/sme-week.html (May 7, 2009)

In case of self-selection, programmes seeking, e.g., to provid support for rapidly growing businesses may see greater participation by growth-propense businesses than by growth-averse or uable" factors. Committee selection refers to programmes where the committee is effective in selecting those firms likely to perform superiorly. Even if the programme did not exist, the selected firms would be expected to have outperformed the other firms participants and matched firms cannot be attributed solely to programme participation.

The overall rate of burdens on wages (including social security, vocational tratining and employer's (onthutions) was planned to decreased from 33.5\% in 2006 to $28.5 \%$ in 2007 (Strategy, 2007)

See also: http://ec.europa.eu/youreurope/business/decidingto-stop/handling-bankruptcy-and-starting-afresh/hungary/index_en.htm, http://web.worldbank.org/WBSITE/EXTERNAL/

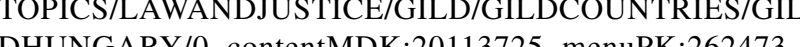
pagePK:157658 piPK:157731 theSitePK:262467,00 html\# pagePK:157658

Hungary is among the countries in which the perceived opportu(GEM, 2008)

The programme included a Micro Credit Programme, a Midi Credit, the Europe Technological Catching-up Investment Credit Programme and the Széchenyi Card, by far the most successful program offering access to a maximum of EUR $40000 \mathrm{credit}$ (inliquidity problems, subject to a simplified procedure, with the state budget providing a $50 \%$ guarantee fee subsidy for every card issued and with a state interest subsidy of $2 \%$.

Government gross consolidated debt, which was $87.4 \%$ in 1995 went down to $52.1 \%$ by 2001 . it increased again to $65.9 \%$ in 2007 and $72.9 \%$ in 2008, by far the highest among the new EU member countries (Staehr, 2010) (Eurostat data).

(the towest in Hungary among the EU-27. ESI is a composite indicator made up of five sectoral confidence indicators with different weights: Industrial confidence indicator, Services confidence indicator, tor, Retail trade confidence indicator-Source: http://epp.eurostat. ec europa eu/tgm/printTable do?tab=table\&plugin=0\&language ec.europa.eu/tgm/printTable.do?tab=table\&plugin=0\&language the current situation and prospects of the Hungarian economy see MNDE 2010a.

Home prices are expected to drop 9\% in 2010 after adjusting for inflation, according to mortgage bank FHB. Prices fell an inflation-adjusted 7.5\% in 2009. http://www.xpatloop.com/news/ home_values_in_hungary_to_decline_this_year (22 March tion-adjusted house prices fell by an average of $4.2 \%$ in 2008 , $5.7 \%$ in $2007,5.3 \%$ in 2006 and $2.7 \%$ in 2005 . Financial (credit and capital programmes) and support schemes for enterprisises amount will be approximately HUF 1,400 billion (approximately $€ 4.8$ billion) in 2009 and 2010 (approximately 5\% of the GDP and 35\% of the total banking SME credit portfolio). To this HUF 900 billion ( $€ 3.1$ billion) loans guarantee should be added (MEH 2009).

The Financial Crisis Survey, implemented in June and July 2009, measures the effects of this crisis on 1,686 firms in six countries in Eastern Europe and Central $A$ sa:

the crisis and rising (particularly among foreign workers, les educated workers and minorities), although not as high as at the 
decade beginning. A significant part of the adjustment has come creased regional labor mobility: employment has consequently contracted less than aggregate economic activity but underenployment has risen. Higher labour mobility and greater willing-Semerak, 2009).

\section{References}

Aidis, R. - Welter, F. (2008) (eds.): Innovation an Entrepreneurship. Successful Start-ups and Businesses in Emerging Economies. Cheltenham: Edward Elgar

Andor, L. (2009): Hungary in the Financial Crisis: A (Basket) Case Study. Debatte, Vol. 17, N 3, December, p. 285296.

APEH (2010): Short Summary on the Taxation of Companie Budapest: Tax and Financial Control Administratio downloaded on 29 March 2010)

Audretsch, D.B. (2006): Entrepreneurship, Innovation and Economic Growth. Cheltenham: Edward Elgar

Barrell - Holland (2010): Fiscal and Financial Responses to the Economic Downturn. No. National Institute Economic Review, $\mathrm{N}^{\circ}$ 211, p. R51-R62. (http://ne March 2010)

CEC (2009): Long-term Sustainability of Public Finances the Commission to the European Parliament and the Council. Brussels: Commission of the European Communities, COM(2009) 545/3 (http://ec.europa eu/economy_finance/publications/publication15996 en.pdf downloaded on 29 March 2009)

Correa - Iootty (2010): The Impact of the Global Economic Crisis on the Corporate Sector in Europe and Central Asia Evidence from a Firm-Level Survey. Enterprise Note $\mathrm{N}$ Note.pdf downloaded on 29 March 2010)

Dallago, B. (1989): The Non-Socialized Sector in Hungary: der Wirtschaft Osteuropas/Yearbook of East-Europea Economics, Vol. 13, No. 2, 1989, p. 67-92.

Dallago, B. (1991): Hungary and Poland: The Non-Socialized Sector and Privatization. Osteuropa-Wirtschaft, Vol. 36, no. 2, June 1991, p. 130-153.

Dallago, B. (2003): Sme Development in Hungary: Legacy, Transition and Policy. in: Robert J. McIntyre and Bruno Dallago (eds.): Small and Medium Enterprises in Transitional Economies. London, Houndmills, Basingstoke: Palgrave Macmillan, p. 78-97.

Dallago, B. - Guglielmetti, C. (2010): Local Economies and Global Competitiveness. Houndmills, Basingstoke: Palgrave Macmillan ness to accept offered position can also be observed. (Svejn (http://en.apeh.hu/taxation/summary_companies.htm sagepub.com/cgi/reprint/211/1/115 downloaded on 26 for a Recovering Economy, Communication from 10 (http://www.enterprisesurveys.org/documents/ECA-

CSO (2006): Small and medium-sized enterprises and Entrepreneurship. Budapest: Central Statistical Office An Attempt at Estimation of its Importance. Jahrbuch

BRD (2007): Transition Report 2007. London: European Bank for Reconstruction and Development

B. Looking Forward. European View, Vol. 8, p. 293-300.

Enon, Medium Enterprises During and After the Financial and Economic Crisis. Bussels: Cente for European Studies, October

Estrin, S. - Hanousek, J. - Kočenda, E. - Svejnar, J. (2009): The Effects of Privatization and Ownership in Transition Economies. Journal of Economic Literature, Vol. 47, N 3, p. 699-728.

Eurostat (2008): Enterprises by size class - overview of SMEs in the EU. Statistics in focus, 31/2008

Fabrizio, S. - Leigh, D. - Mody, A. (2009): The Second Transition: Eastern Europe in Perspective. IMF Working Paper WP/09/43, March

$B D$ (2007): Hungarian bankruptcy and corporate legislation revised. Freshfields Bruckhaus Deringer, March (http://www.freshfields.com/publications/pdfs/2007/ mar07/17710.pdf

Fodor, P. - J. Poór (2009): The Impact of the Economic and Financial Crisis on HRM and Knowledge-Management in Hungary and Slovakia - Empirical Research 2008-2009. Acta Polytechnica Hungarica, Vol. 6, No 3, p. 69-91.

Frydman, R. - Rapaczynski, A. (1994): Privatization in Eastern Europe: Is the State Withering Away?, Budapest: Central European University Press

GEM (2008): Global Entrepreneurship Monitor. 2008 Executive Report (http://www.gemconsortium.org/ download/1243443355808/GEM_Global_08.pdf)

Gries, T. - Naudé, W. (2010): Entrepreneurship and structural economic transformation. Small Business Economics, Vol. 34, $\mathrm{N}^{\circ} 1$, January, p. 13-29.

Hodorogel, R.G. (2009): The Economic Crisis and its Effects on SMEs. Theoretical and Applied Economics, http:// www.ectap.ro/articole/389.pdf (downloaded on 29 March 2010)

Horváth, A. - Gy. Körmendi (2009): Change in Domestic Housing Prices. Hungarian Central Bank, Report on Financial Stability, Update, November

MF (2009): Hungary: First Review Under the StandBy Arrangement and Request for Modification of Performance Criteria. IMF Country Report No. 09/105

Claessens, S. - Dell'Ariccia, G. - Igan, D. - Laeven, L. (2010): Lessons and Policy Implications from the Global Financial Crisis. IMF Working Paper WP/10/44 (http://www.imf.org/external/pubs/ft/wp/2010/wp1044. pdf downloaded on 29 March 2010)

JEREMIE (2007): SME Access to Finance in Hungary, Joint European Resources for Micro-to-Medium Enterprises Evaluation Study, European Investment Fund

Kauffman Foundation (2007): On the Road to an Guide, Version 2.0 (www.kauffman.org)

VEZETÉSTUDOMÁNY
Kornai, J. (1986): The Hungarian Reform Process: Visions, Hopes and Reality. Journal of Economic Literature, Vo $24, \mathbf{N}^{\circ} 4$, p. $1687-1737$.

Kornai, J. (1990): Road to a Free Economy. New York: W.W. Norton

Laki, M. (1998): Kisvállalkozás a szocializmus után (Small Entrepreneurship after Socialism). Budapest: Közgazdasági Szemle Alapítvány

McIntyre, R. J. - Dallago, B. (2003) (eds.): Small and Mediun Enterprises in Transitional Economies. Houndmills, Basingstoke: Palgrave Macmillan

MEH (2009): Crisis and Growth. Strategy for a Strong Hungary, Prime Minister's Office, Budapest, 5 March 2009 http://www.meh.hu/misc/letoltheto/Valsag_es novekedes_ENG.pdf

$M N B$ (2009): Report on Financial Stability. Central Bank of Hungary, April (http://english.mnb.hu/Engine. aspx?page=mnben_stabil\&ContentID $=12307$ )

$M N B$ (2010a): PressreleaseontheMonetaryCouncil'smeetin of 25 January 2010. (http://english.mnb.hu/Engine. asp $x$ ?page $=$ mnben_monet_kozlem\&ContentID=13649 downloaded on 29 March 2009)

$M N B$ (2010b): Minutes of the Monetary Council Meeting on 22 February 2010. (http://english.mnb.hu/engine. aspx?page=mnben_mt_jegyzokonyv downloaded on 29 March 2009)

MNDE (2008): State of Small and Medium-Sized Business in Hungary 2007. Budapest: Ministry for National Development and Economy

MNDE (2009): Overview of the Competitiveness of the Hungarian Economy. Budapest: Ministry for Nationa Development and Economy, Strategy Department, 31 December (http://www.nfgm.gov.hu/data/cms752852/ competitiveness_200912_overview.pdf downloaded on 29 March 2010)

$M N D E$ (2010a): Overview of the Current Situation and Prospects of the Hungarian Economy. Budapest: Ministry for National Development and Economy, Economic Policy and Analysis Department, 16 March (http://www. nfgm.gov.hu/data/cms684788/macro_100315_ENG. pdf downloaded on 29 March 2010)

MNDE (2010b): Overview of the Domestic Lending Rates. Budapest: Ministry for National Development and Economy, Economic Policy and Analysis Department, 16 February (http://www.nfgm.gov.hu/data/cms2018298/ lending_2009q4_ENG.pdf downloaded on 29 March 2010)

MoET (2007a): State of Small and Medium-Sized Business in Hungary 2005-2006. Budapest: Ministry of Econony and Transport

MoET (2007b): SMEs Access to Finance, Analysis of Market Falures. Budapest: Ministry of Economy and Transport, May

MoET (2008): Hungary - Operational Programme 20072013: Economic Development. Ministry of Economy and Transport, 16 October (http://www europa eu/rapid/
pressReleases Action do?reference=MEMO/08/628\&fo rmat $=\mathrm{PDF} \&$ aged $=0 \&$ language $=\mathrm{EN} \&$ guiLanguage $=\mathrm{en}$ ) Evelutionary and Radical Approaches to Economic Reform. Economics of Planning, Vol. 25, N 1, p. 79-96.

I (2007): Removing Barriers to SME Access to Int (2007): OECD Fris. OECD

SME SME and Entrepreneurship Policies and Programmes.

I Ansuring Entrepreneurship. A Digest of Indicators. OECD-Eurostat Entrepreneurship Indicators Progris

A An

En Entrepreneurship Financing and Policy Responses. Paris: pdf downloaded on 29 March 2010)

OECD-Intesa (2009): Turin Round Table on the Impact of the Global Crisis on SME \& Entrepreneurship Financing and Policy Responses. Issues Paper, Turin: OECD and Intesa Sanpaolo, 26-27 March, http://www.oecd.org/ dataoecd/37/4/42514259.pdf downloaded on 29 March 2010

Popov, A.A. - Udell, G.F. (2010): Cross-Border Banking and the International Transmission of Financial Distress during the Financial Crisis of 2007-2008. January, http://www.sed.manchester.ac.uk/research/events/ conferences/developmenteconomics/papers/Popov_ Udell.pdf, downloaded on 29 March 2010

Ramalho, R. - Rodríguez-Meza, J. - Yang, J. (2009): How are Firms in Eastern and Central Europe reacting to the Financial Crisis? Enterprise Note $\mathrm{N}^{\circ}$ 8, Wahington, D.C: The World Bank (http://wwwenterprisesurveys. org/documents/EnterpriseNotes/Note8 pdf downloaded on 29 March 2009)

Rodrik, D. (2007): One Economics, Many Recipes. Princeton and Oxford: Princeton University Pres

Sachs, J. (1993): Poland's Jump to the Market Economy. Cambridge, Mass.: MIT Press

Chitz H. (2004): Local Enterprises in the Global Economy. Cheltenham: Edward Elgar

Overview of Changes to Insolvency: Bankruptcy Law. Journal of International Banking Law and Regulation, Vol. $22, \mathrm{~N}^{\circ}$

Staehr, K. (2010): The Global Financial Crisis and Public Finances in the New EU Countries from Central and Eastern Europe. Bank of Estonia, Working Paper Series 2/2010

Stein, H. (2010): Financial Liberalisation, Institutional Transformation and Credit Allocation in Developing Countries: The World Bank and the Internationalisation of Banking. Cambridge Journal of Economics, Vol. 34 p. 257-273. 
Strategy (2007): Strategy for the Development of Small and Medium-sized Enterprises (2007-2013). Budapest: Ministry of Economy and Transport, (http://www.nfgm. gov.hu/data/cms1553600/SMEs_Strategy_2007_2013. pdf), 15 April 2009

Svejnar, J. - Semerak, V. (2009): New Member Countries' Labour Markets during the Crisis. University of Michigan, 4 November, (http://www.internationalpolicy. umich.edu/policy\%20briefs/svejnar-semerak-newmember-countries-labour-markets-during-the-crisis.pdf sdownloaded on 29 March 2010)

Szirmai, P. (2003): The Capital-less Capitalism: Review of Hungarian Small Enterprises. in: I. Lengyel (ed.): Knowledge Transfer, Small and Medium-Sized Enterprises, and Regional Development in Hungary. Szeged: JATEPress, p. 122-129.

Vandenberg, P. (2009): Micro, Small and Medium-sized Enterprises and the Global Economic Crisis Impacts and Policy Responses. Geneva ILO

WB (2009): Financial Crisis (http://www.enterprisesurveys. org/financialcrisis/ downloaded on 29 March 2010)

Williamson, J. (1994) (ed.): The Political Economy of Policy Reform. Washington, D.C.: The Institute of International Economics
Winkler, A. (2010): The Financial Crisis: A Wake-Up Call for Strengthening Regional Monitoring of Financial Markets and Regional Coordination of Financial Sector Policies? Asian Development Bank Institute, ADBI Working Paper Series, N¹99, February

World Bank (2009a): Doing Business 2009. Washington D.C.: World Bank

World Bank (2009b): Doing Business 2009: Hungary. Washington D.C.: World Bank

UN (2005): UN Global E-government Readiness Report 2005 From E-government to E-inclusion. New York: Department of Economic and Social Affairs Division for Public Administration and Development Management, United Nations

Völfinger Zs. (2005): Coverage of the Hungarian Business Register. Joint UNECE/Eurostat Seminar on Business Registers, Luxembourg, 21-22 June 2005, Working Paper No 3, 26 May 2005 (http://www.unece.org/stats/ documents/ces/sem.53/wp.3.e.pdf (15 April 2009)

Article provided: 2011. 10.

Article accepted: 2012. 3.

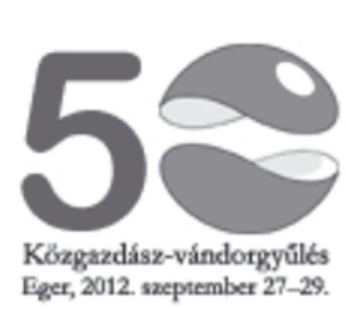

\section{KÖZGAZDÁSZ-VÁNDORGYÜLÉS}

\section{Fontos és kerek évfordulóhoz érkezett 2012-ben a Magyar Közgazdasági Tár- saság: \\ Átalakulás és konszolidáció a magyar gazdaságban és gazdaságirányításban}

címmel immár az 50. Közgazdász-vándorgyúlést rendezzük meg 2012. szeptember 27. és 29. között Egerben. A jubileumi közgazdász-vándorgyúlés programtervezete és jelentkezési lapja már letölthetố a honlapunkon, és várhatóan augusztus elsó napjaiban elindul az on-line regisztráció is (http://www.mkt.hu/ hirek.php?w=368).

A közgazdász-vándorgyúlések a hazai közgazdász szakma legrangosabb és legnagyobb éves összejövetelei: a háromnapos tanácskozások plenáris és szekcióülésein vezetố gazdaságpolitikusok - jelenlegi és volt kormánytagok, szakpolitikusok -, a pénzügyi és üzleti élet kulcsszereplói, gazdaságkutatók, akadémikusok és egyetemi tanárok tartanak előadásokat a mintegy 400-700 fôs, hazai és határainkon túli magyar közgazdászokból álló hallgatóság elôtt. A vándorgyuúlés szeptember 27-én, csütörtökön délután - hagyományainkhoz híven - egy plenáris üléssel veszi kezdetét. A rendezvény második napja a szekcióüléseké lesz: délelőtt öt szekcióban (tervezés és államháztartás; vállalati gazdálkodás; bankok és finanszírozás; külkereskedelem és tốkekapcsolatok; informatika) vitathatják meg az egyes területek kérdéseit a résztvevő́k. Pénteken délután gazdaságpolitikai plenáris üléssel folytatódik a program. A zárónapon, szombaton délelốtt pedig a Költségvetési Tanács tart majd „rendkivüili nyílt ülést” a plenáris ülés hallgatósága előtt.

Meggyőződésünk, hogy a jubileumi, 50. Közgazdász-vándorgyuúlés méltó helyszínen, az egri Park Hotelben, a Magyar Közgazdasági Társaság hagyományaihoz híven tartalmas vitákkal járul majd hozzá ahhoz, hogy minél szélesebb körú szakmai párbeszéd övezze a magyar gazdaságpolitika alakítását. 